\title{
Analysis of Gender Empowerment in Building a Family Economy: A Case Study of a Group of Women of Receiving Credit from the Save and Loan Program in the PNPM Program at Maros District, South of Sulawesi
}

\author{
Muhammad Yunus Amar'1, Humriati² and Alimuddin Unde ${ }^{3}$ \\ ${ }^{1}$ Hasanuddin University, Indonesia \\ ${ }^{2}$ Hasanuddin University, Indonesia \\ ${ }^{3}$ Hasanuddin University, Indonesia
}

\begin{abstract}
This study aims to determine: 1). The influence of the level of information dissemination on the level economic community; 2)the influence of the level of community understanding of the economic level of the community, and 3) the influence of the level of community participation on the economic level of the credit recipient of SPP - PNPM program. This research uses an explanatory approach. The population is 566 members of the PNPM SPP group, and 85 samples are taken by proportionate stratified random sampling technique. Data collection is done by questionnaires, observation and documentation. Data analysis techniques use path analysis with the help of SPSS 16.0 program. The results showed that: 1 ). there is a positive and significant level of information dissemination on the economic level of the community;2) there is a positive and significant level of community understanding of the economic level of the community ;3) there is a positive and significant level of community participation in the economic level of the people receiving PNPM MP SPP credit.

Keywords: information dissemination, level of understanding, level of participation, economic level of the community.
\end{abstract}

\section{Introduction}

Success in achieving the target of implementing a development program is not solely based on the ability of government officials, but also relating to empowerment efforts in the form of participation and independence of the community in the development. (Adisasmita, 2006; Wahyuni, Sri. 2006; Hikmat, Harry, 2004). Community participation in development is an active process where people take the initiative, think for themselves and use tools and processes that they can control themselves. In terms of community empowerment in a development for the case of Maros Regency, on the one hand, where the community adheres to a masculine culture (men), that is, men are still regarded as the main actors and determinants in supporting the family economy, the role of women sustaining the family economy is still considered marginal. On the other hand, according to the 2015 BPS data, it shows that the percentage of the population of women is greater than the percentage of the population of men. On the other hand, according to the 2015 BPS data, it shows that the percentage of the population of women is greater than the percentage of the population of men. Which means that the potential for women's participation in family economic development is greater. This phenomenon becomes interesting to study with regard to the existence of a government program called the National Community Empowerment Program - Independent Rural (PNPM-MP), one of which is the empowerment of women to improve the family economy called the savings and loan program for women's groups (SPP). The question is the extent to which the role of the women's group through the program in improving the family economy.

In addition, the presence of the PNPM SPP is expected to reduce the number poor households in the sub-district. Based on BPS data in 2014, the percentage of poor households in 2012 was $14.97 \%$ to $12.23 \%$ in 2014 , which means there was a decrease in poor households by $2.74 \%$.

Information dissemination of the PNPM SPP program is very important as one of the communication processes where each communication activity is expected to achieve the desired results. The group 
of women who participated in this program, in geographies, were in rural areas far from the city so that communication media that could be used were limited.

Another obstacle that often arises towards the program of increasing community participation internally is the attitude of the community groups themselves, including this group of women, who are reluctant to be directly involved in an activity program because of the low understanding of the importance of the PNPM SPP program so that they do not actively convey what they need.

Based on the above phenomenon, it is interesting to examine the extent of information dissemination and of the understanding and of the participation of women's community groups in the existence of the National Community-Independent Rural Empowerment Program (PNPM-MP), especially the Savings and Loan Program for women's groups, and its relationship with improving the family economy.

Communication and Development Theory. The objectives of development communication are, among others, changing behavior and opinion, realize community participation, and social change and improve community income (Nora C. Quebral (1975), Alan B. Chalkley (1970).

Alan B. Chalkley (1970) argues that at least a development communicator is in charge: a. Describe facts about the way of life in terms of economics; b) Promote it so that the way of life can be understood by the public; c). Awareness of the importance of the development program so that they want to participate and be involved in it; d) Be aware of and act on possible solutions to problems poverty that bound the people.

The participation communication model was made by Lawrence Kincaid and Everett M. Rogers, in Cangara (2012: 51), explaining that in a centralized communication process, each actor tries to interpret and understand the information he receives as well as possible, then convey the results of his thoughts well other people.

Concept of Information Dissemination. Dissemination of information is an activity of delivering new things, new policies, new ways to deal with or overcome phenomena that occur in various fields of life (Rogers, 1983; Sastropoetro, 1990; Achmad, 1990); Information is a basic element implicitly inherent in the concept of planned development. Any development activity can only take place and reach the desired target, if at each stage: planning, implementation and supervision are based on adequate information (Dahlan, 1997).

Information dissemination has an important goal that the development program delivered can be accepted by the target group (Cangara, 2012). Because the dissemination of information has an indispensable role, especially if the target is not identified.

Schramm in Nasution (1996) formulated the main tasks of communication in a social change in the framework of national development, namely: (1) conveying to the public information about national development, so that they focus on the need for change, opportunities and ways to make changes, and generate national aspirations, (2) provide an opportunity for the community to take an active part in the decision-making process, expand dialogue to involve all parties who will make decisions about change, provide opportunities for community leaders to lead and listen to small people's opinions, and create information flows that running smoothly from below to the top.

Equitable development is only possible if done in line with the distribution of information and communication (Dahlan, 1997). Most information cannot reach the lowest level of community structure because it uses formal networks, because people who sit on formal networks have their own social networks and this social network is considered more important.

Equitable information and communication are needed in various ways the field of poverty alleviation, such as economics and welfare people. Information gaps in the economic field can reduce opportunities get a good business and income. In the field of welfare people, information gaps can hamper the effectiveness of various services community service which is the basis for quality improvement community life.

Concept of Community Understanding. Angle (in Murray and Lappin, 1976), suggests some factors that influence a person's participation in activities at the environment, are: age, work, income, 
education, and time stay somewhere. Individuals with middle to upper age tend to actively participate in activities in their environment. The activity in participating is the implementation of knowledge obtained from information or experience in his life. A person's understanding of an object has an intensity or different levels.

Concept of Community Participation. Participation is an important component in generation independence and empowerment process (Craig and May, 1995) in Wisdom (2004: 24). Hikmat (2004: 26) explains that empowerment and participation are potential strategies in order to improve economic, social and cultural transformation. This process will ultimately create development peoplecentered.

Koentjaraningrat (2000), that community participation in the implementation of development emphasizes more on one's own willingness to carry out development activities through self-help and mutual assistance and donations volunteer. Without community participation the continuity of development will experience significant obstacles. Therefore, every development program clearly requires the participation of community members.

Koentjaraningrat (2000), that community participation in the implementation of development emphasizes more on one's own willingness to carry out development activities through self-help and mutual assistance and donations volunteer. Without community participation the continuity of development will be obtained significant obstacles. Therefore, every development program clearly requires the participation of community members.

The Concept of Building a Family Economy. Through community and family-minded development, in every movement of development, the government will always carefully consider the dimensions of society and family as targets and actors.

For poor families who have a micro-scale business in productive economy, the main problem faced to build the family economy is limited business capital (Ismawan, 2003). Therefore, providing capital for their productive efforts will increase the income and welfare of their families.

Family empowerment comes from individual empowerment, and then community empowerment comes from family empowerment. This prompted the government to empower families through efforts to develop an independent and prosperous family economy with the program women's group participation in SPP-PNPM.

By using Skiner's Stimulus - Organism - Response (SOR) theory, and the participation Communication Model by Lawrence Kincaid, namely that the stimulus sourced from the PNPM - MP program will get a response from the women's group as far as disseminating information about the program 's objectives (Davidoof 1988), and will shape community participation (Rogers, Everett M, 1983 ) to realize the achievement of the objectives of the program, namely to build and to improve the family economy independently.

Factors that directly influence the acceptance of information are knowledge related to that information, and attitudes and behavior towards information (Oetomo, 2002). By receiving information from a program, it will give birth to a level of understanding of the objectives of the program, which in turn can arouse community participation in running the program. Then, with the participation of the community to participate in a program it will improve the economy and better living standards of the community.

Based on the basic assumptions of the theory of Stimulus Theory - Organisms - Response (S-O-R) from (Hovland), and the participation Communication Model was made by Lawrence Kincaid and Everett M. Rogers, that causes that can change attitudes depend on the quality of the stimulus received by the organism. So the participation of the target community in the SPP - NPM Program in developing the family economy depends on PNPM's ability to disseminate information about the PNPM SPP program and the level of understanding of the target community. Groove thought like the following model. 


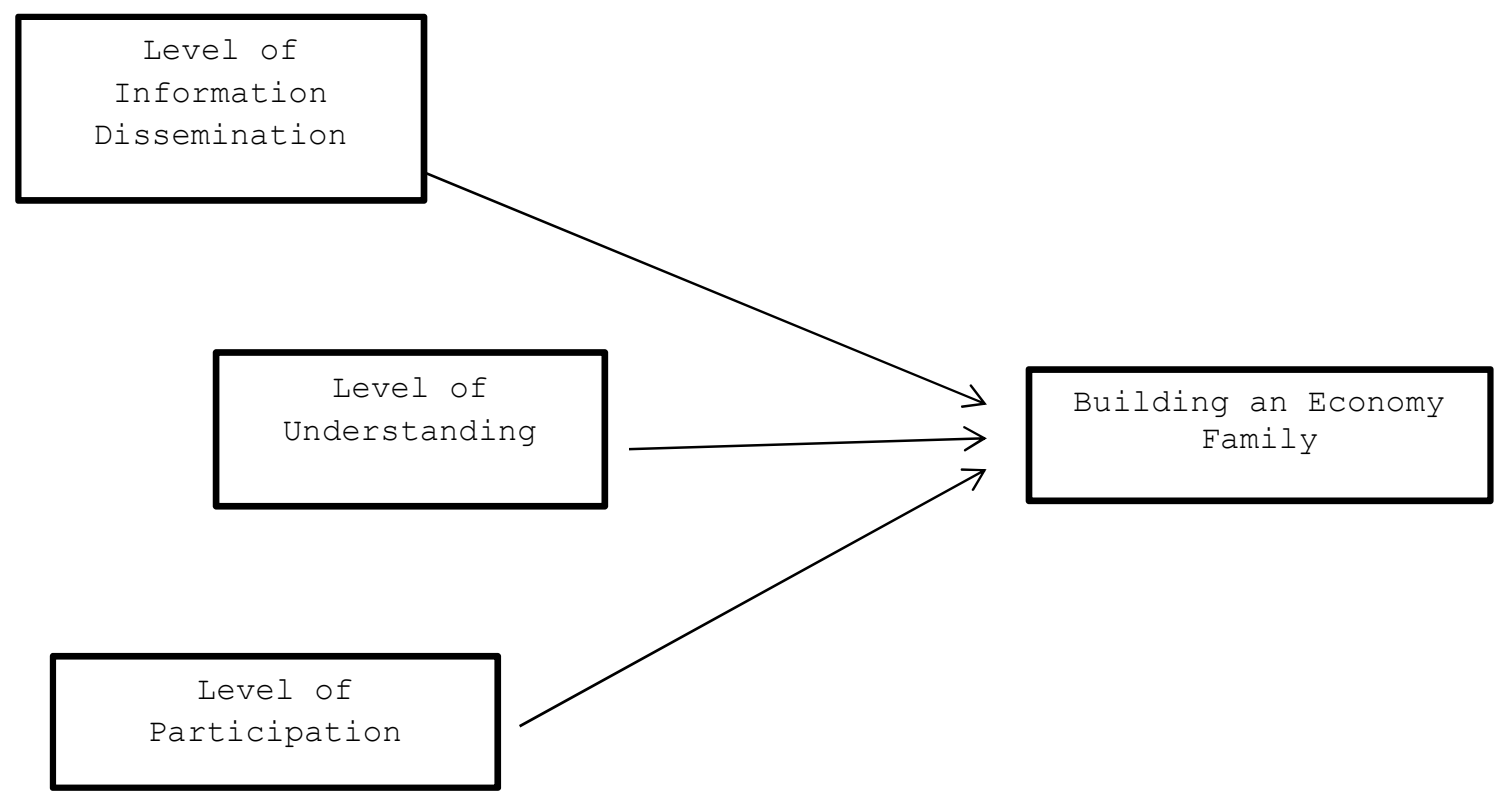

Figure 1. Research model

\section{Research Methodology}

This study uses a survey method. The population is all groups of women who joined in receiving capital funding from the Women's Group Savings and Loans Program (SPP) - the National Rural Empowerment Community (PNPM) Program located in Cenrana sub-district, Maros Regency, which is 566 people. The size of the sample, using the stratified random sampling technique using the solvin formula, is 85 people.

The technique of collecting data through questionnaires was compiled with Likert's Summated Rating. Data analysis using Path Analysis with the help of SPSS for Windows Program.

The model of the relationship between variables is as follows:

$\mathrm{Y}=p Y 1 \mathrm{X} 1+p Y 1 \mathrm{X} 2+p \mathrm{Y} 1 \mathrm{X} 3+\varepsilon_{1}$

Where :

$\mathrm{Y} 1$ = Building a family economy

$\mathrm{X} 1=$ Level of Dissemination information of PNPM SPP Program

X2 = Level of Family Understanding of PNPM SPP Program

X3 = Level of Family Participation of PNPM SPP Program

$\varepsilon 1,2=$ Other factors

\section{Result and Discussion}

Based on Table 1, the results show that X1 has a p-value of 0.002 smaller than the significance level $(\alpha)$ of 0.05 or $5 \%$, which means that the level of information dissemination (X1) has a significant effect on the family economy level. X2 has a p-value of 0.037 smaller than the significance level $(\alpha)$ of $0.05,5 \%$, which means that the level of understanding (X2) has a significant effect on the family economy level; and X3 has a p-value of 0.0001 smaller than the significance level $(\alpha)$ of $0.05,5 \%$, which means that the level of family participation (X3) has a significant effect on the family economy level. 
Table 1. Calculation results of path analysis with SPSS for Windows program

\begin{tabular}{|c|c|c|c|c|}
\hline Model & Path coefficient & t-value & p-value & Significance \\
\hline $\begin{array}{cc}\mathrm{X} 1 \quad(\mathrm{p} & \mathrm{YX} 1) \\
& 0,271 \\
& 3,151 \\
& 0,002\end{array}$ & 0,271 & 3,151 & 0,002 & Yes \\
\hline 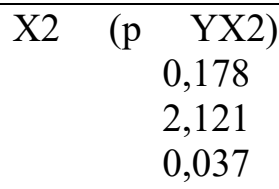 & 0,178 & 2,121 & 0,037 & Yes \\
\hline X3 (p YX3) & 0,478 & 5,408 & 0,000 & Yes \\
\hline
\end{tabular}

Source : The result of Processing data by SPSS for Windows.

The level of information dissemination of the PNPM SPP program has a significant effect on economic level of family members of PNPM SPP recipients in Cenrana District Maros Regency. This finding is in accordance with what was stated by Roger (1983) which states that communication in development holds important role because communication is the basis of social change. Disseminating communication messages that are informative, persuasive, and systematically instructive to the target can get results optimal (Effendy (1981).

The level of understanding of the PNPM SPP program has a significant effect the economic level of families of PNPM SPP recipients in the District Cenrana, Maros Regency. With a high level of understanding about the objectives and benefits of the PNPM SPP Program have implications for a better family economic level.

The Family Group will carry out the rules and instructions for implementing the PNPM SPP Program so that the objective of this program is achieved, namely, to improve the economy of the user community. A low level of understanding is indicated by the utilization of credit received not in accordance with what is written in the proposal that they submitted. Some of the SPP group members did not really understand that the credit provided was for business development and improving their family's economy.

The level of family group participation in terms of their involvement in the planning stage, the implementation stage and the stage of utilization of PNPM SPP activities has an effect on increasing the family income. They are actively making group plans, implementing programs that are in line with the objectives of PNPM SPP will bear fruit in increasing their income.

\section{Conclusion}

The conclusion from the results of the discussion above is that the level of information dissemination, and of understanding and of participation of PNPM SPP credit recipient groups has a positive and significant impact on the economic level of their families. Furthermore, to find out other factors, such as the role of mentoring and the credibility of officers towards the successful achievement of the objectives of the PNPM program, further studies are needed.

\section{References}

Adisasmita, Rahardjo. 2006. Building Participatory Villages. Graha Ilmu.Yogyakarta.

Central Bureau of Statistics, 2013. District of Cenrana in 2013 Figures,Maros.

Central Bureau of Statistics, 2014. District of Cenrana in Figures for 2014,Maros. 
Cangara, Hafied and Moh. Abduh and Andi Alimuddin Unde. 2007. Textbook: Basics of Communication Theory, FISIP UNHAS, Makassar

Dahlan, M.Alwi, 1997, Equitable Information, Communication and Development, Speech for Inauguration of Professor of Communication Studies at FISIP UI, Depok.

Danudiredja D.E. 1998. Relationship between Characteristics and Communication Behavior P3DT Assistance Recipient with Perception and Participation in Implementation of the P3DT Program in Sukabuni Regency, West Java, Bogor:Post-graduate of IPB.

Harun, Rochajat and Elvinaro Ardianto. 2012. Development and Communication Social change. PT. RajaGrafindo Persada, Jakarta.

Hikmat, Harry, 2004, Community Empowerment Strategy, Revised Edition, Humaniora Utama Press, Bandung.

Hovland. I L Janis. \& H Kelley. (1953) Communication and Persuation, New Heaven Conn: Jale University Press.

Ismawan, Bambang. (2003), The Role of Microfinance Institutions, Journal of Indonesia Economy $\&$ Business, Faculty of Economics, UGM, Yogyakarta.

Koentjaraningrat. 2000, Mentality and Development Culture, Gramedia, Jakarta Smeru Research Institute, Research Report "Qualitative Study of Impacts PNPM Rural in East Java, West Sumatra and Sulawesi Southeast, Jakarta.

Lewis, Philip V. 1980, Organizational Communication: The Essence of Effective Management, Grid Publishing, Ohio.

Nasution, 1996, Principles of Communication for Extension, FE - UI, Jakarta South Sulawesi Provincial Government, 2013. Provincial Regulation South Sulawesi Number 10 of 2013 concerning Plans Regional Medium-Term Development (RPJMD) of Sulawesi Province South of 2013-2018, Makassar.

Ross, Murray G., and B. W Lappin, 1976, Community Organization: theory, principles and practices, Second Edition, Harper and Row Publishers, New York.

Uma. 2003. Research Methods for Business: A Skill-Building Approach, 3th, NY: John Wiley and Sons, New York.

Sujarweni, V. Wiratna, 2014. SPSS for Research, New Library Press, Yogyakarta.

PNPM District UPK Cenrana District, 2015, PNPM UPK Financial Report Cenrana District, Maros Regency in February 2015, Cenrana,Maros.

Uphoff, NT Cohen JM, and Goldsmith. 1979. Development Committee:Feasibility and Application of Rural Development Participation 'A State of-the arth paper. New York: Cornell University.

Christiani, Charis. 2012, Journal of the Effect of National Program Implementation Community Empowerment (PNPM) Against Economic Enhancement Community in Gemuhblanten Village, Gemuh District, District Kendal, FISIP Untag, Semarang.

Goma S. 2004. Development of Revolving Fund Credit in Empowering Community Economy (Case of the Tega Rejo Village in Poso District City of Poso Regency, Central Sulawesi Province). [thesis]. Institute Bogor Agriculture, Bogor.

Lestarini, Purwati, 2013. Journal of the Effect of SPP Credit (Savings and Loans) Women's Group) PNPM - MP on Revenue Society, Veteran IKIP, Semarang.

Sisvianda, Devina K, 2013, Communication Strategy for PNPM-MP Assistance in an effort to provide program understanding to the community (Study on SPP activities in Kemuning Lor Village, Arjasa District - Jember Regency), Faculty of Social and Political Sciences, Malang.

Wahyuni, Sri. 2006. Process of Communication and Participation in Development Village Community, Case of Village Raksa Program in District Ciampea Bogor Regency [Thesis], Bogor Agricultural Institute, Bogor.

Alan B. Chalkley, Susanto Agus, June 12, 2012. Communication and Development (http://agustocom.blogspot.com/2012/06/komunikasidan-development. html. accessed November 28, 2014). 